\title{
PERANCANGAN MEDIA PEMBELAJARAN KOMIK DIGITAL LABORATORIUM SEJARAH RUMAH ARCA SEBAGAI UPAYA PENGENALAN SEJARAH LOKAL
}

\author{
Fauzi Rachman dan Yuliani SW \\ Program Studi Pendidikan Sejarah, Universitas Veteran Bangun Nusantara \\ Email: fauzirachman.veteranbantara@gmail.com
}

\begin{abstract}
Abstrak
Tujuan dari penelitian ini adalah mengetahui: potensi sejarah lokal Laboratorium Sejarah Rumah Arca Univet Bantara Sukoharjo; perancangan media pembelajaran komik digital Laboratorium Sejarah Rumah Arca Universitas Veteran Bangun Nusantara Sukoharjo sebagai upaya pengenalan sejarah lokal kepada remaja. Model penelitian yang digunakan adalah penelitian kualitatif yaitu dengan observasi, wawancara, dokumentasi dan studi pustaka untuk mendapatkan data-data yang digunakan sebagai pendukung pembuatan konsep perancangan media. Data dianalisis dengan menggunakan beberapa tahap, yakni reduksi data, penyajian data, dan kesimpulan. Berdasarkan Perancangan Media Pembelajaran Komik Digital Laboratorium Rumah Arca Univet Bantara Sukoharjo sebagai upaya pengenalan sejarah lokal kepada remaja dapat disimpulkan penggunaan dapat menjadi alternatif media pembelajaran efektif dan efisien untuk menarik remaja belajar tentang peninggalan sejarah khususnya sejarah lokal Kabupaten Sukoharjo.
\end{abstract}

Kata kunci: Media Pembelajaran Sejarah, Komik Digital, Laboratorium Rumah Arca, Sejarah Lokal

\section{DESIGN OF DIGITAL COMIC LEARNING MEDIA OF ARCA HOUSE HISTORICAL LABORATORY AT AS RECOGNITION EFFORT OF LOCAL HISTORY}

\author{
Fauzi Rachman dan Yuliani SW \\ History of Educational Program, Veteran Bangun Nusantara University \\ Email: fauzirachman.veteranbantara@gmail.com
}

\begin{abstract}
The purpose of this research is to know the potential of local history of Historical Laboratory of Arca House at Univet Bantara Sukoharjo; Designing digital comic learning media of arca house historical laboratory at Veteran Bangun Nusantara Sukoharjo University as recognition effort of local history to teenagers. The research model uses qualitative research that is by observation, interview, documentation and literature study to get the data used as supporting of making media design concept. Data were analyzed using several stages, ie data reduction, data presentation, and conclusion. Data were analyzed using several stages, they are data reduction, data presentation, and conclusion. Based on the Design of Digital Comic Learning Media of Arca House Laboratory Univet Bantara Sukoharjo as an effort to introduce local history to the teenagers can be concluded that the use Digital comics can be an alternative of learning media which is effective and efficient to attract teenagers learning about historical relics especially local history of Sukoharjo District
\end{abstract}

Key Words: $\quad$ Historcal Learning Media, Digital Comics, Arca House Laboratory, Local History 


\section{PENDAHULUAN}

Sebagai daerah bekas wilayah Kraton Kasunanan Surakarta, lingkungan Kabupaten Sukoharjo merupakan wilayah yang banyak ditemukan peninggalan sejarah terkait dengan keberadaan Kraton Surakarta, sekaligus menjadi area peristirahatan Raja - Raja Kraton Kasunanan Surakarta. Oleh karena itu, keberadaan Kabupaten Sukoharjo merupakan bagian dari satu kesatuan tidak terpisahkan dengan Kraton Kasunanan Surakarta. Kabupaten Sukoharjo menjadi unik karena lingkungan berbagai jenis peninggalan sejarah berupa artefak dan bentuk bangunan bersejarah yang bercirikan arsitektur tradisional khas Kraton Kasunanan yang dipengaruhi arsitektur agama Hindu - Budha dengan pola ruang yang khas. Kekhasan ini yang menjadikan lingkungan Kabupaten Sukoharjo masuk dalam kawasan cagar budaya yang ada di Kota Solo, dan sekaligus merupakan peninggalan yang bernilai sejarah lokal. Banyak benda bersejarah yang saat ini disimpan di laboratorium sejarah Univet adalah identitas tertentu suatu daerah di Kabupaten Sukoharjo. Benda-benda kuno tersebut seperti lumpang yang dulu pernah ditemukan di daerah Gatak. Ada pula berupa lingga dan yoni yang berukuran besar yang kini masih berada di Desa Pengkol, Kecamatan Nguter. Sedangkan di Langenharjo, Kecamatan Grogol, juga pernah ditemukan arca. benda-benda bersejarah yang berada di berbagai daerah di Sukoharjo itu perlu diperkenalkan kepada masyarakat. Salah satu cara untuk memperkenalkan itu yakni dengan wisata sejarah. Potensi benda cagar budaya yang berwujud Lingga dan Yoni perlu untuk diperkenalkan kepada siswa seKabupaten Sukoharjo karena, artefak ini masih banyak ditemukan dan koleksikoleksi yang disediakan di Laboratorium Rumah Arca Univet Bangun Nusantara Sukoharjo sudah pantas untuk dikunjungi sebagai wahana pembelajaran sejarah lokal Kabupaten Sukoharjo.

Sejarah lokal Kabupaten Sukoharjo menjadi hal yang asing bagi sebagian siswa, karena sejarah lokal hanya dapat ditelusuri dari jejak peninggalan, bukti artefak dan bangunan bersejarah yang tidak begitu jelas sumber informasi dari pelaku serta saksi sejarah. Seperti halnya dengan sejarah lokal di Kabupaten Sukoharjo, yang sampai sekarang masih banyak siswa yang belum tahu atau 
bahkan tidak mau tahu. Padahal untuk mempelajari sejarah Kabupaten Sukoharjo tidak sulit, karena sudah disediakan wahana Laboratorium Sejarah Rumah Arca Universitas Veteran Bangun Nusantara Sukoharjo yang khusus mempelajari bangunan bersejarah peninggalan Kraton Kasunanan Surakarta yang bercorak Hindu - Budha. Laboratorium Sejarah Rumah Arca yang berlokasi di kompleks Kampus Universitas Veteran Bangun Nusantara Sukoharjo. Namun, siswa SMA sekitar Laboratorium Sejarah Rumah Arca kurang tertarik untuk berkunjung, karena Laboratorium Rumah Arca dianggap sebagai sebuah tempat yang membosankan. Untuk itulah perlu adanya suatu media yang dekat dengan kehidupan siswa sekarang yang serba digital (digital native) sekarang ini.

Menarik untuk diadakan pengembangan media berbentuk komik digital yang berfungsi merangkum secara lengkap tentang apa saja yang ada di Laboratorium Rumah Arca tersebut. Dimana komik digital tersebut akan dibuat menarik sehingga tidak adanya kebosanan bagi remaja dalam membaca buku tersebut. Menarik maksudnya dengan membuat sebuah komik digital yang memasukkan media gambar untuk mengilustrasikan berbagai koleksi Laboratorium Rumah Arca dalam media komik digital Laboratorium Rumah Arca sehingga dapat dibaca atau dipelajari. Oleh karena itu, penelitian ini bertujuan untuk merancang komik digital Laboratorium Sejarah Rumah Arca Universitas Veteran Bangun Nusantara sebagai media pembelajaran peninggalan sejarah lokal siswa SMA Kabupaten Sukoharjo.

\section{METODE PENELITIAN}

Perancangan ini menggunakan metodologi penelitian kualitatif yang berlandaskan pada filsafat postpositivisme. Metode ini digunakan untuk meneliti pada kondisi obyek yang alamiah, dimana peneliti adalah sebagai instrumen kunci. Pengambilan sampel sumber data dilakukan secara purposive dan snowbaal. Sedangkan teknik pengumpulan data dilakukan dengan triangulasi (observasi, wawancara dan dokumentasi). Analisis data pada penelitian ini bersifat induktif/kualitatif berdasarkan fakta-fakta yang ditemukan di lapangan dan kemudian dikonstruksikan menjadi hipotesis atau teori. Hasil penelitian kualitatif lebih menekankan makna dari pada generalisasi (Sugiyono, 2009: 15). 
Teknik pengumpulan data cenderung pada observasi berperan serta (participan observation), wawancara mendalam (in depth interview) dan dokumentasi (Sugiyono, 2009: 309). Teknik analisis data dilakukan sejak awal penelitian dan selama proses penelitian itu berlangsung. Data diperoleh melalui wawancara, observasi, serta dokumentasi. Setelah itu data diolah secara sistematis. Adapun prosedur dalam menganalisis data kualitatif, menurut Miles dan Huberman (2014) dalam Sugiyono (2009: 91-99) adalah reduksi, penyajian data, dan kesimpulan

\section{HASIL DAN PEMBAHASAN}

Analisa studi pendahuluan dalam penelitian perancangan ini mengacu pada observasi yang telah dilakukan terhadap lingkungan obyek yang diteliti,yaitu lingkungan yang dikelola oleh pengurus Laboratorium Sejarah Rumah Arca Univet Bantara Sukoharjo yang berisi tentang keadaan koleksi arca, pemetaan jenis koleksi, dan potensi koleksi Laboratorium Sejarah Rumah Arca.

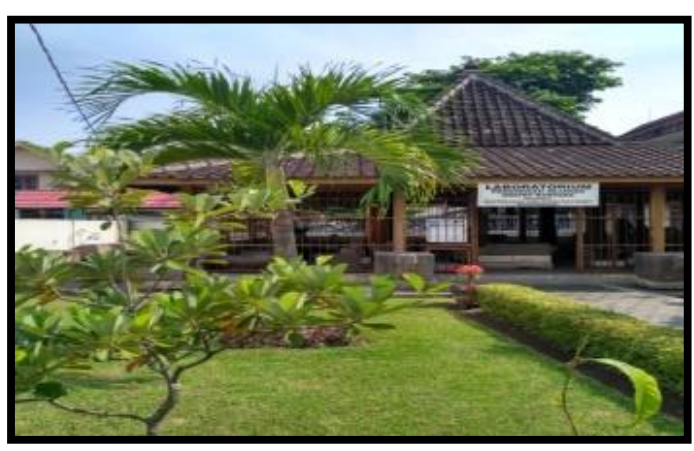

Gambar 1. Laboratorium Rumah Arca Aspek-aspek yang terdapat pada Peninggalan cagar budaya di Yoni dan Lingga Rumah Arca Univet Bangun Nusantara Sukoharjo yang dapat dikembangkan menjadi sumber belajar sejarah di SMA adalah sebagai berikut:

Aspek Bentuk Yoni dan Lingga Rumah Arca Univet Bangun Nusantara Sukoharjo yaitu berupa lingga, yoni, arca kuno, dan batu megalitik. Lingga merupakan peninggalan yang berasal dari masa Hindu yang memiliki bentuk lonjong seperti phallus (alat kelamin laki-laki). Yoni merupakan peninggalan yang berasal dari masa Hindu yang memiliki bentuk bulat dan ditengahtengahnya terdapat lubang bundar. Arca kuno merupakan peninggalan cagar budaya yang memiliki bentuk seperti manusia akan tetapi bentuk dan ukirannya masih sangatlah sederhana. Sementara batu megalitik merupakan sebuah batu peninggalan yang berasal dari masa prasejarah yang memiliki 
bentuk bundar layaknya batu yang sering dijumpai di sungai-sungai.

Aspek Historis Peninggalan cagar budaya di Yoni dan Lingga Rumah Arca Univet Bangun Nusantara Sukoharjo terbagi menjadi berbagai periode sejarah berdasarkan masa pembuatannya, seperti masa prasejarah, masa berkembangnya kebudayaan Cina, dan masa Hindu. Sehingga peninggalan ini memiliki karakter yang berbeda satu dengan lainnya. Aspek sejarah pada peninggalan cagar budaya di Laboratorium Rumah Arca Univet sangat penting dalam kehidupan masa lalu, masa kini dan masa yang akan datang. Hal ini terkait dengan jejakjejak sejarah yang tersimpan di dalam peninggalan tersebut yang bisa dikembangkan menjadi sumber sejarah yang lebih efektif dan inovatif dalam merekonstrusksi sebuah peristiwa sejarah di masa lampau. Selain itu, nilai-nilai sejarah yang terdapat dalam peninggalan peninggalan tersebut dapat memperkuat dan memperkokoh jati diri bangsa serta memupuk nilai nasionalisme;

Aspek Religius yaitu Secara substansial peninggalan cagar budaya di Yoni dan Lingga Rumah Arca Univet Bangun Nusantara Sukoharjo memiliki nilai-nilai religi yang dianut oleh masyarakat terdahulu setempat sehingga makna religi pada peninggalan cagar budaya di Yoni Rumah Arca Univet Bangun Nusantara Sukoharjo tidak dapat terlepas dari unsur-unsur antropologi religi tersebut diatas, yaitu: Emosi keagamaan (getaran jiwa) muncul karena masyarakat di Kabupaten Sukoharjo pada masa lampau yang meyakini bahwa peninggalan cagar budaya di Yoni Rumah Arca Univet Bangun Nusantara Sukoharjo merupakan tempat atau sebagai media untuk memuja Dewa Siwa beserta manifestansinya. Selain itu, eksistensi peninggalan-peninggalan cagar budaya yang terdapat di Yoni Lingga Rumah Arca Univet Bangun Nusantara Sukoharjo yang terus dijaga dan dilestarikan oleh masyarakat setempat mengindikasikan adanya getaran jiwa yang sejak dahulu sudah terpelihara dengan baik sebagai sebuah keyakinan terhadap Dewa Siwa yang telah melindungi dan memberikan anugrahnya bagi seluruh masyarakat Kabupaten Sukoharjo. Sistem kepercayaan, yaitu masyarakat meyakini bahwa manifestasi Tuhan yang bersthana di Yoni Lingga Rumah Arca Univet Bangun Nusantara 
Sukoharjo yang sering disebut dengan Bhatara dapat memberikan berkah dalam menempuh kehidupan. Krama yakin bahwa Yoni Rumah Arca Univet Bangun Nusantara Sukoharjo dihuni oleh manifestasi Tuhan yaitu BhataraBhatari dalam bentuk dan wujud serta nama.

Aspek Budaya, Peninggalan cagar budaya di Yoni dan Lingga Rumah Arca Univet Bangun Nusantara Sukoharjo tidak dapat dilepaskan dari aspek budaya karena peninggalanpeninggalan tersebut hasil ciptaan manusia pada masa lalu yang berbudaya. Secara umum peninggalan cagar budaya di Yoni Lingga Rumah Arca Univet masyarakat Kabupaten Sukoharjo pada masa lalu yang sangat religius dan memperhatikan aspekaspek keTuhanan dalam menjalankan segala bentuk aktifitasnya.Nilai-nilai budaya tersebut sangat penting tidak hanya untuk masyarakat Kabupaten Sukoharjo akan tetapi seluruh masyarakat Indonesia yang secara historis terkait dengan peninggalanpeninggalan tersebut. Kesadaran jati diri suatu bangsa banyak dipengaruhi oleh pengetahuan di masa lalu bangsa yang bersangkutan sehingga keberadaan kebangsaan itu pada masa kini dan proyeksinya ke masa depan bertahan pada ciri khasnya sebagai bangsa yang tetap berpijak pada landasan filsafat dan budayanya sendiri. Aspek-aspek tersebut nantinya akan dimasukan dalam silabus pembelajaran sejarah di sekolah.

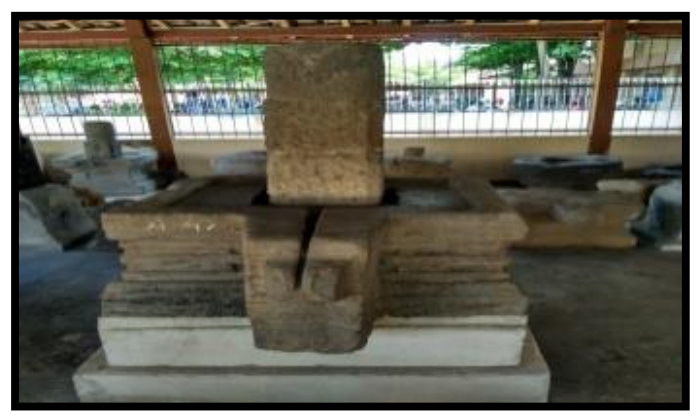

Gambar 2. Aspek Bentuk Yoni

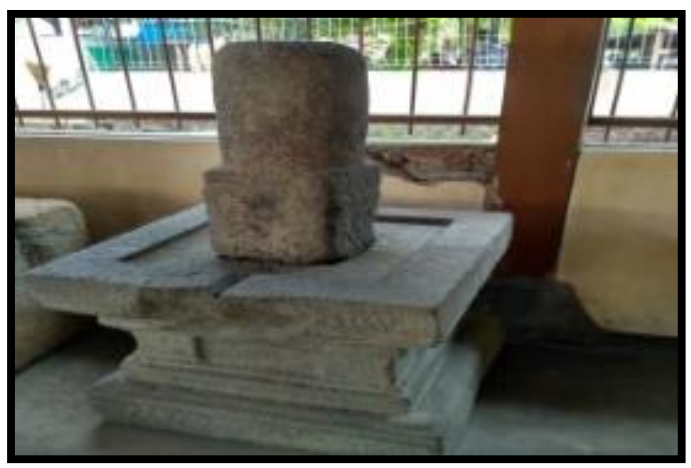

Gambar 3. Aspek Historis Yoni

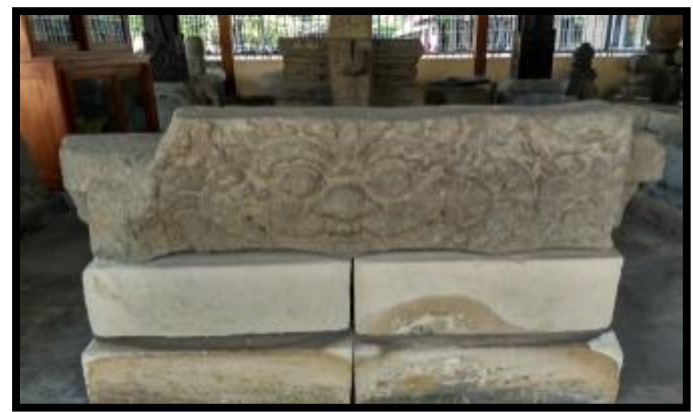

Gambar 4. Aspek Religius Yoni

Masalah yang muncul disebabkan materi sejarah lokal Kabupaten Sukoharjo yang tidak ada dalam 
kurikulum dan waktunya yang terbatas hanya 1 jam pelajaran. Adanya penolakan dari sekolah ketika kunjungan sejarah karena dapat mengganggu kegiatan belajar mengajar. Untuk itulah diperlukan pengembangan media yang dapat dimanfaatkan di dalam kelas.

Kurikulum 2013 memberi kesempatan yang lebih leluasa kepada sejarah. Ke depan kunjungan sejarah pengembangan media berbentuk komik digital ke dalam semua kelas. Sekolah tentu akan mendukung dan mengijinkan mengingat kurikulum yang digunakan adalah kurikulum 2013 yang lebih menonjolkan sejarahnya dan mewajibkan siswa untuk mencaritahu sendiri.

Pemilihan kata kunci atau keyword dari perancangan buku digital Laboratorium Rumah Arca Univet Bantara Sukoharjo ini dipilih dengan menggunakan dasar acuan terhadap analisis data yang sudah dilakukan. Penentuan keyword diambil berdasarkan Model Pembelajaran Gerlach dan Ely.

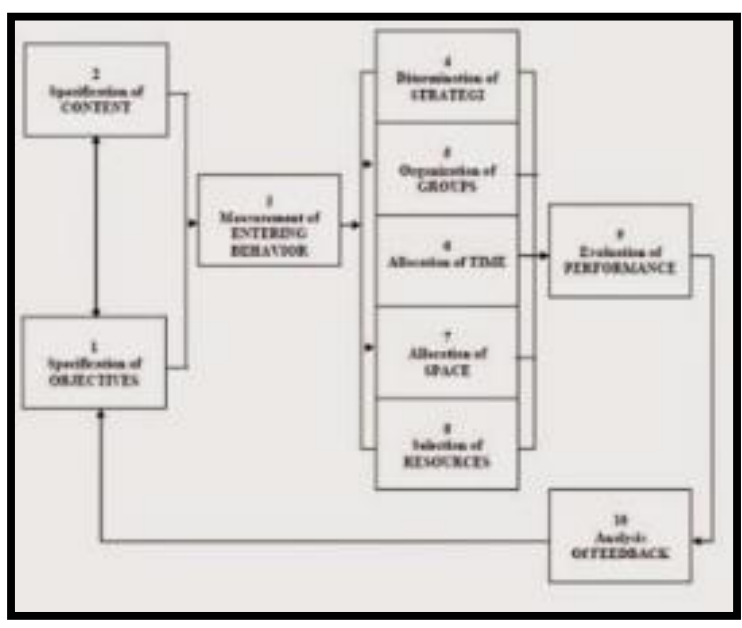

Gambar 5: Model Pembelajaran

Sumber: Gerlach dan Ely, 1971: 11

Model pembelajaran merupakan suatu cara yang sistematis dalam mengidentifikasi, mengembangkan, dan mengevaluasi seperangkat materi dan strategi yang diarahkan untuk mencapai tujuan pendidikan tertentu. Model Gerlach dan Ely menetapkan pemakaian produk teknologi pendidikan sebagai media dalam menyampaikan materi. Dalam hal ini dipilih media buku digital. Pemilihan media ditentukan menurut tanggapan siswa yang disepakati, sehingga fungsinya tidak hanya sebagai stimulus rangsangan belajar siswa.

Penentuan keyword juga diambil berdasarkan identifikasi pasar. 


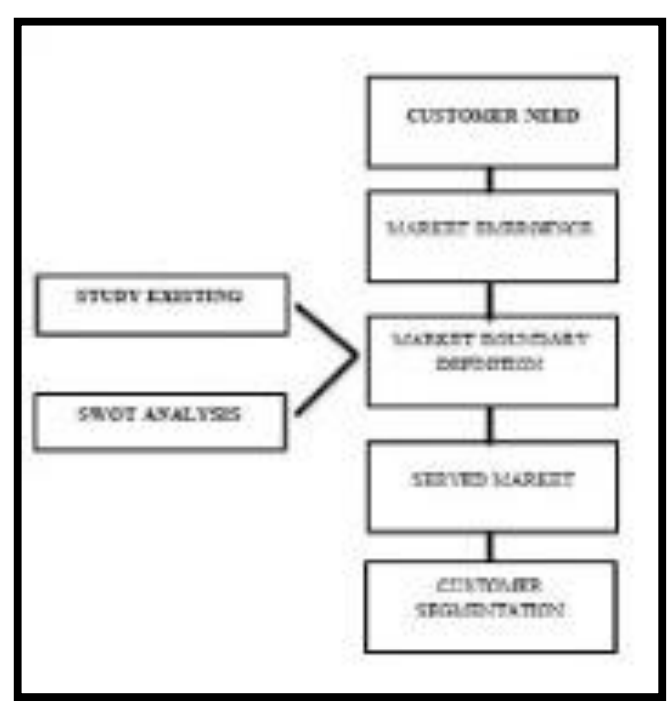

Gambar 6: Identifikasi Pasar

Sumber: Jain, 2000: 107

Berikut ini adalah Perancangan Komik Digital Laboratorium Sejarah Rumah Arca Univet Bantara Sukoharjo:

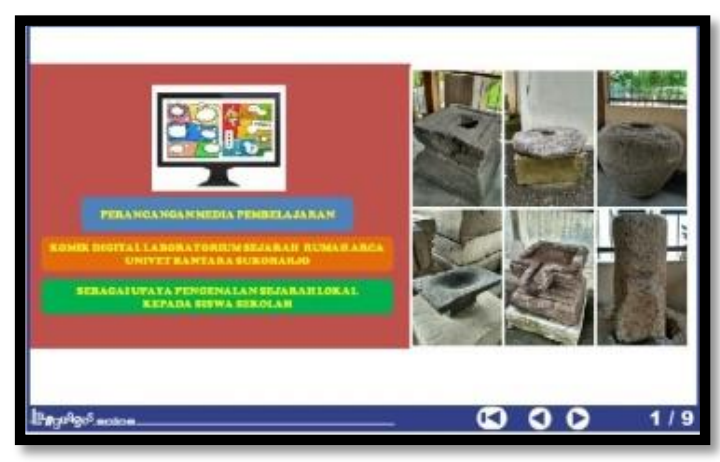

Gambar 7. Cover Komdig

Lab Rumah Lab

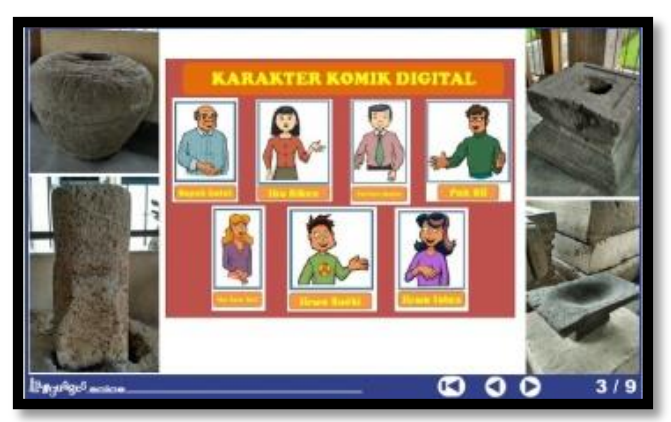

Gambar 8. Karakter Komdig Lab Rumah Arca
Konsep komik digital dipilih berdasarkan target siswa SMA yang sudah dewasa. Komik digital dibuat dengan ilustrasi nyata berdasarkan karakter siswa yang mampu memahami keberadaan sejarah lokal koleksi Laboratorium Rumah Arca Univet Bantara Sukoharjo secara fakta lapangan.

Selain itu juga diberikan ilustrasi gambar dan tokoh komik pada keadaan lingkungan Laboratorium Rumah Arca sesuai koleksi asli sebenarnya. Ilustrasi gambar dan tokoh komik memberikan informasi kepada siswa secara menarik dan menyenangkan. Hal ini ditujukan untuk memunculkan ketertarikan dan semangat pembaca serta untuk mengurangi tingkat kebosananan pembaca.

Pada ilustrasi gambar menonjolkan profil, benda koleksi bersejarah kebudayaan Kabupaten Sukoharjo dalam komik digital tersebut dibuat sebagai Ruthatarbelekapge disesuaikan tokoh komik yang menyampaikan informasi yang penting sehingga pengetahuan tentang sejarah lokal Kabupaten Sukoharjo akan efektif dalam penyampaiannya. Dengan penyampaian yang efektif ditujukan untuk memberikan kesan bahwa komik digital akan mendidik pembaca dengan media yang menarik dan menyenangkan. 
Selain itu dengan membaca ringkas dan pendek akan mempercepat proses pembelajaran efektif yang mampu memberikan pemahaman yang baik, kecerdasan, ketekunan, kesempatan dan mutu serta dapat memberikan perubahan perilaku dan mengaplikasikannya dalam kehidupan tentang peninggalan sejarah lokal di lingkungan sekitar.

Berdasarkan rangkuman hasil penelitian ada temuan yang menarik bahwa pemanfaatan komik digital secara efektif dan efisien mampu menarik motifasi siswa terhadap sejarah lokal, terutama pada saat event Museum Goes to Campus I (2016) di Kampus UNS Surakarta, Jawa Tengah. Hasil penelitian ini sesuai dengan hasil penelitian yang dilakukan oleh Hangho Jeung yang dilakukan di Korea Selatan (2010) bahwa inovasi pembelajaran menggunakan media serupa komik digital yaitu media buku digital satu temuannya adalah bahwa ternyata siswa menunjukkan kepuasan dengan dan mengakui kegunaan e-book tetapi tetap menyukai p-book atau buku cetak. Walaupun siswa belum sepenuhnya menyerah pada p-book namun e-book mulai menjadi semakin umum. Hangho Jeung mengatakan bahwa tantangannya adalah bagaimana membuat e-book yang dikatakan mampu meningkatkan pemahaman pembaca tetapi juga mengurangi efek kelelahan mata. Penelitian yang hampir sama yaitu oleh William H. Walters, di Amerika Serikat (2013) bahwa media pembelajaran atau multimedia interaktif dapat membangkitkan motivasi Hasil penelitian menyebutkan bahwa potensi keuntungan dari teknologi e-book dapat dimaksimalkan, namun perpustakaan akademik menghadapi tantangan yang besar terkait dengan pemilihan, perizinan, akuisis dan manajemen ebook. Kondisi keseimbangan pemanfaatan media pembelajaran digital dengan media pembelajaran cetak hendaknya dimanfaatkan secara efektif dan efisien, dengan adanya kemajuan dunia digital diharapkan dimanfaatkan sehingga pembelajaran berjalan efektif, efisien dan berdaya tarik.

\section{SIMPULAN DAN SARAN}

Penggunaan komik digital secara efektif dan efisien mampu meningkatkan motifasi belajar siswa pada sejarah. Penggunaan komik digital yang tepat artinya disesuaikan dengan kondisi dan karakteristik bidang yang ditelitik dan obyek studi, karakteristik 
siswa, serta tujuan pembelajaran yang telah ditetapkan. Berdasarkan hasil penelitian yaitu perancangan komik digital laboratorium rumah arca mendapatkan apresiasi dari siswa yang cukup signifikan Penggunaan multimedia interaktif secara tepat mampu meningkatkan hasil belajar siswa pada IPS Sejarah. Peningkatan motifasi mempelajari sejarah lokal dapat dilihat melalui kunjungan siswa SMA Kabupaten Sukoharjo mengunjungi Laboratorium Sejarah Rumah Arca Univet Bantara Sukoharjo. Peningkatan ini tentu dikarenakan adanya perbaikan materi pembelajaran sejarah lokal dengan memanfaatkan sumber sejarah lokal setempat dokombinasikan dengan media digital, salah satunya adalah optimalisasi media digital, dalam hal ini komik digital.

Tolok ukur pemilihan media pembelajaran bukan pada kecanggihan, tetapi keefektifan, efisiensi dan daya tarik bagi siswa. Oleh karena itu, sebagai seorang dosen dan guru dituntut tepat dalam memilih media yang efektif dan efisien, dan variasikan penggunaan media agar semua gaya belajar siswa dapat tercapai.

\section{DAFTAR PUSTAKA}

Direktorat Museum, Ayo Kita Mengenal Museum, Direktorat Museum, Direktorat Jendral Sejarah dan Purbakala, Departemen Kebudayaan dan Pariwisata. Jakarta, 2009.

Garraghan, Gilbert J. 1957. A Guide to Historical Method. New York: Fordham University Press

Gerlach dan Ely. 1971. Teaching \& Media: A Systematic Approach. Second Edition, by V.S. Gerlach \& D.P. Ely, 1980, Boston, MA: Allyn and Bacon. Copyright 1980 by Pearson Education

Hariyono. 1995. Mempelajari Sejarah Secara Efektif. Jakarta: Pustaka Jaya.

Isjoni . 2007. Pembelajaran Sejarah. Bandung : Alfabeta

Jain, S. C. 2000. Marketing Planning \& Strategy 6th Edition. New Jersey: Prentice Hall.

Jeong, Hanho. 2010. A Comparison of the Influence of Eleltronic Books and Paper Books on Reading Comprehension, Eye, Fatigue, and Perception. Dalam www.emeraldinsight.com diunduh 01 Desember 2016 pukul 10.00.

Keeves, John. 2002. 'Learning in Schools: A Modelling Approach'. International Educational Journal. 3 (2): 114 - 124 in www.iej.cjb.net, accesed on December $02^{\text {nd }}, 2016$ at $08.30 \mathrm{am}$.

Miles,M.B, Huberman,A.M, dan Saldana,J. 2014.Qualitative Data Analysis, A Methods Sourcebook Edition 3. USA : Sage Publications

Smaldino, Sharon E., dkk. 2011. Learning Technology and Media for Learning: Teknologi Pembelajaran dan Media 
untuk Belajar Edisi Kesembilan. Jakarta: Kencana Prenada Media Group.

Sugiyono. 2009. Metode Penelitian Pendekatan

Kuantitatif, Kualitatif dan R \& D. Bandung: Alfa Beta.
Walters, William H. 2013. E-Books in Academic Libraries: Challenges for Acquisitio and Collection Management. Diunduh 30 November 2016 pukul 10.00 